\title{
Modulation of the Process of Aging in Human Organism: Recent Advances in Biomarkers for Diagnosis and Treatment
}

\author{
Dimitrios Tsoukalas $^{a, b}$, Persefoni Fragkiadaki \\ Evangelia Sarandi ${ }^{\mathrm{a}, \mathrm{b}}$ and Aristidis Tsatsakis*a \\ ${ }^{a}$ University of Crete \\ Voutes University Campus, Heraklion, Crete, GR-70013, Greece \\ ${ }^{b}$ Health Clinics for Autoimmune \& Chronic Diseases \\ 5 Koumpari Str., Athens, 10674, Greece
}

Received 11.02.2018, received in revised form 02.04.2018, accepted 19.05.2018

\begin{abstract}
Aging is a complex biological process. Main factors that interplay in the aging process include free radicals and oxidation, insulin and insulin growth factors, sirtuins, mTOR, microbiome, lack of micronutrients, and declining proteasome activity which lead to cellular damage. Damaged cells are being replaced by somatic stem cells which proliferate to generate new cells. For each cell replication the telomeres of the related stem cells become shorter and this is the basic factor that modulates aging. Telomere length shortens with age and leads to senescence. Shorter telomeres are associated with increased incidence of aging related diseases and shorter lifespan. The percentage of short telomeres and rate of telomere shortening predicts longevity in mammals. Measurement of single telomeres through Q-FISH is the only reliable method to evaluate single telomere length and percentage of short telomeres. Repeated measurements at a distance of 6 months or a year can reveal the rate of change of the short telomeres, and response of patients to treatments, lifestyle, diet, supplementation and exercise modifications. A natural product telomerase activator TA-65, an astragalus extract, has been found to lengthen telomere in humans. By experimenting with different combinations of cycloastragenol (astragalus extract active molecule) we've able to increase telomerase activation in relation to the control cells.
\end{abstract}

Keywords: aging, telomeres, telomere length, telomerase.

Citation: Tsoukalas D., Fragkiadaki P., Sarandi E., Tsatsakis A. Modulation of the process of aging in human organism: recent advances in biomarkers for diagnosis and treatment. J. Sib. Fed. Univ. Biol., 2018, 11(2), 146-156. DOI: 10.17516/1997-13890057 .

(C) Siberian Federal University. All rights reserved

* Corresponding author E-mail address: aris@med.uoc.gr 


\title{
Модулирование процесса старения в организме человека: последние достижения в области биомаркеров \\ для диагностики и лечения
}

\author{
Д. Цукалас ${ }^{a, 0}$, П. Фрагкиадаки \\ Е. Саранди ${ }^{\mathrm{a}, \boldsymbol{\sigma}}$, А. Тсатсакис ${ }^{\mathrm{a}}$ \\ ${ }^{a}$ Университет Крита \\ Грециия, GR-70013, Крит, Ираклион, Университетский кампус Воутес \\ ${ }^{6}$ Клиника здоровья для аутоиммунных и хронических заболеваний \\ Греция, 10674, Афиньл, ул. Коумпари, 5
}

Старение - это сложный биологический прочесс. Основные факторы, участвующие в прочессе старения и приводящие к повреждению клеток, включают свободные радикалы, прочессы окисления инсулина, инсулиноподобные факторы роста, сиртуины, mTOR, микробиом, отсутствие микроэлементов и снижение активности протеасом. Поврежденные клетки заменяются соматическими стволовыми клетками, которые размножаются, генерируя новые клетки. При каждой клеточной репликации теломеры родственных стволовых клеток становятся короче, и это основной фактор, который модулирует старение. Длина теломер сокращается с возрастом и приводит к старению. Более короткие теломеры ассоииируются с увеличением заболеваний, связанных со старением и сокращением продолжительности жизни. Данные о процентном содержании коротких теломер и скорости сокращения теломер позволяют предсказать продолжительность жизни млекопитающих. Измерение отдельных теломер с помощью Q-FISH является единственным надежным методом оиенки длины теломеры и доли коротких теломер. Повторные измерения через 6 месяцев или год могут выявить скорость изменения длины коротких теломер и реакиию пациентов на лечение, изменение образажизни, диеты, пищевых добавок и физической активности. Было обнаружено, что натуральный продукт - активатор теломеразы ТА-65, экстракт астрагала, удлиняет теломеры людей. Экспериментируя с различными комбинациями иуиклоастрагенола (активная молекула экстракта астрагала), мы смогли достичь активаџии теломеразы по сравнению с контрольными клетками.

Ключевые слова: старение, теломера, длина теломеры, теломераза.

\section{Introduction}

Aging is a process characterized by progressive decline of organ functions, increased incidence of age-related diseases and mortality (Cui et al., 2012; Romano et al., 2010). Although diseases associated with aging are mistakenly referred as diseases of the elderly, they are markedly distinct. Age-related diseases include cardiovascular disease (CAD, stroke), cancer, arthritis, osteoporosis, cataracts, diabetes, type 2, hypertension, chronic obstructive pulmonary disease and dementia (WHO, 2011). Epidemiological data show that they are responsible for $2 / 3$ of the global death burden, 
while they account for $90 \%$ of disease in the industrialized world. Roughly 150.000 people die every day and 100.000 of them die due to ageassociated causes, making aging the greatest risk factor for death and disease. Non-communicable diseases (NCD) are the most common health problem in older age and their incidence is closely related to wealth. Heart disease, stroke, and chronic lung disease are the biggest killers of older people worldwide, though in low-income countries older people carry a greater disease burden than those in the rich world (Prince et al., 2015). Previous studies have described telomere length as promising emerging biomarker for use in colorectal cancer which is placed in the third place among the most diagnosed cancer in men (Nikolouzakis et al., 2018). Age-related diseases cause disability through sensory impairments, back and neck pain, chronic obstructive pulmonary disease, depression, falls, diabetes, Alzheimer disease, and osteoarthritis (Frasca et al., 2017). Previous studies have summarized the current state of knowledge on the role of telomeres in mental disorders with the most common being depression, schizophrenia and stress-anxiety. Most studies report reduced telomere length in patients suffering from mental disorders, compared to the general population. Since the factors that can affect telomere length are various, more experiments and investigations are required to understand the general impact of different factors on telomere length (Vakonaki et al., 2018).

The term aging refers to the increase of biological age and not the chronological. There is only a weak association between biological age with a person's age in years. Indeed, some 80 -year-olds have physical and mental capacities similar to 20 years-old individuals. Also, health in older age is not random. Although some of the differences in older people's health reflect their genetic inheritance, most are due to epigenetic factors, their physical and social environments. It's important to note that epigenetic factors start to influence aging since childhood (Benayoun et al., 2015).

\section{Aging is a multifactorial process}

Several factors have been suggested to interplay in aging, including free radicals and oxidation, mitochondrial dysfunction, insulin and insulin growth factors, sirtuins, mTOR, microbiome, lack of micronutrients and declining proteasome activity (Fig. 1). The biological significance and their role in the process of aging will be further discussed.

Free radicals and oxidation have been long suggested to be the leading cause of aging, while another theory indicates mitochondrial dysfunction as the key player (Romano et al., 2010). Oxidative stress reflects the imbalance between the production of reactive oxygen species (ROS) and the antioxidant defenses. The free radical theory stated that oxidative stress causes damage to cell components - proteins, lipids, and DNA through the release of excessive free radicals (Betteridge, 2000).

Mitochondrial dysfunction theory of aging is a modification of the free radical theory, and suggests that cumulative damage to the mitochondria and their DNA (mtDNA) caused by free radicals is the central factor of aging (Payne \& Chinnery, 2015).

Insulin and insulin growth factor-I (IGF-I) reduced signaling predict increased longevity in organisms ranging from yeast to mammals (Parrella et al., 2015; Milman et al., 2014). Disruptions of the circadian rhythm, the natural feeding and the fasting cycle facilitates increased calorie intake and contribute to metabolic diseases that may accelerate the aging process. Alternating periods of feeding with periods of fasting, as in time restricted feeding, fast mimicking diets and periodic or intermittent 


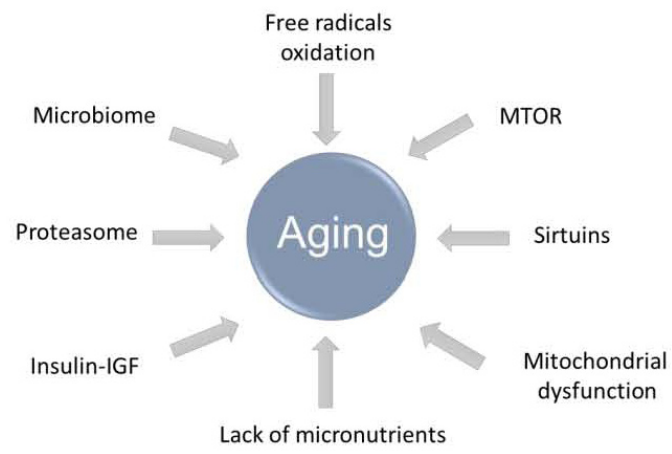

Fig. 1. Factors affecting aging. The multifactorial process of aging is affected by free radicals and oxidation, mammalian target of rapamycin (mTOR), sirtuins, dysfunction of mitochondria, lack of micronutrients, insulin and insulin growth factor (IGF), decline of the proteasome activity and the microbiome

fasting, impart pleiotropic benefits have been associated with the down regulation of IGF-1 and improvement of insulin sensitivity (Lee et al., 2014). Metformin protective effects against several age-related diseases in humans have been associated with decreased insulin resistance and IGF-1 signaling. Those effects will be tested in the TAME (Targeting Aging with Metformin) trial. Insulin and IGF-1 are also central regulating factors for the SIRT-1 (sirtuin) and mTOR pathways (Watroba \& Szukiewicz, 2016; Barzilai et al., 2016).

Sirtuins are a class of nicotinamide adenine dinucleotide (NAD+)-dependent deacetylases, and have been suggested to be potent in prevention of aging and age-related diseases, and even reverse aspects of aging (Bonkowski \& Sinclair, 2016). Sirtuins contribute to cellular regulation of many metabolic functions related to aging, including DNA repair, autophagy, apoptosis, genome stability, and mitochondrial functions (Watroba \& Szukiewicz, 2016).

The mTOR (mechanistic target of rapamycin) pathway directly influences protein synthesis, transcription, autophagy, metabolism, and organelle biogenesis and maintenance (Lipton \& Sahin, 2014). Inhibition of the mTOR pathway has a protective effect against age-related diseases and extends lifespan in model organisms.
Several mTORinhibitors have been approved for a variety of clinical uses, and others are under clinical development. Adverse side effects currently hinder the use in healthy individuals, though encouraging early data suggest that drugs targeting the mTOR pathway could be widely used to slow aging and reduce age-related pathologies in humans (Johnson et al., 2013).

The microbiome is a population of microbes that form a "meta-organism" comprising of ten bacterial cells for each human cell. The microbiome plays a critical role in modulating the rate of the phenotype of aging. Diffusible molecules released by the bacteria directly affect cells of the host, and recent studies indicate that these interspecies signaling impacts host aging rate (Heintz \& Mair, 2014).

Lack of micronutrients accelerates aging through mitochondrial decay, DNA damage, such as chromosome breaks, and metabolic disruption. Most people are characterized by inadequate dietary intake of vitamins and minerals, most likely due to excessive consumption of high calorie, micronutrient-poor, processed food. Poor nutrition is linked to increased risk of many agerelated diseases, including cancer, heart disease, and diabetes (Ames, 2006).

Reduced ability to maintain a proteostasis and a functional proteome is one of the hallmarks 
of aging. Under normal conditions, degradation of damaged proteins occurs through efficient proteolysis by the ubiquitin-proteasome system. With age, damaged and misfolded proteins accumulate due to the inefficient function of the proteasome pathway and impair cell function and tissue homeostasis. The accumulation of damaged proteins occurs in multiple age-associated pathologies such as Alzheimer's, Parkinson's or Huntington's disease (Vilchez et al., 2014).

\section{The common denominator}

All these mechanisms cause cellular damage, which eventually brings to autophagy and cell apoptosis. Damaged cells are replaced by tissue stem cells which divide every time to generate new tissue cells. Adult somatic stem cells reside in specific tissues within most of our organs, possess self-renewal capacity and can repair or replace cells and tissues damaged by injury or disease. These cells are stored in a protected environment niche, where they are connected to supporting cells, and kept dormant until an appropriate activating signal. Tissue-specific adult stem cells proliferate to replace senescent or deteriorated cells, maintaining the organ structure and function. They can repair mild injuries in various organs and tissues including the skin, liver, intestine, kidney, and bone marrow
(Montagnani et al., 2016). Aging coincides with a decreased regenerative capacity of stem cells and shortening of telomeres.

\section{Telomere length and aging}

Telomeres' functional role is to prevent gene loss from enzymatic nucleotide degradation and genome instability. Repetitive 5'-TTAGGG-3' sequences of 70 to 100 nucleotides bound to telomeric interacting proteins provide a protective cap of the chromosomal DNA, resembling the end of a shoelace (Fig. 2). To exert DNA repair mechanisms, single-stranded telomeric DNA form T-loop structures at the tip of chromosomes (Griffith et al., 1999). Normal diploid cells lose telomeric DNA during DNA replication due to the end replication problem. Thus, somatic cells have a certain lifespan until they reach a critically short length which will result in one of the following cell fates: senescence, cell death by apoptosis, genomic instability due to the fusion of telomeres. Fused chromosomes break unequally in mitosis, leading to genomic instability and chromosomal rearrangements during cell divisions (Muraki et al., 2012; O'Sullivan \& Karlseder, 2010). On the other hand, cells with high proliferation capacity (i.e., germ cells, adult stem cells) manage to avoid chromosome erosion by expressing telomerase, an RNA-dependent DNA polymerase which binds

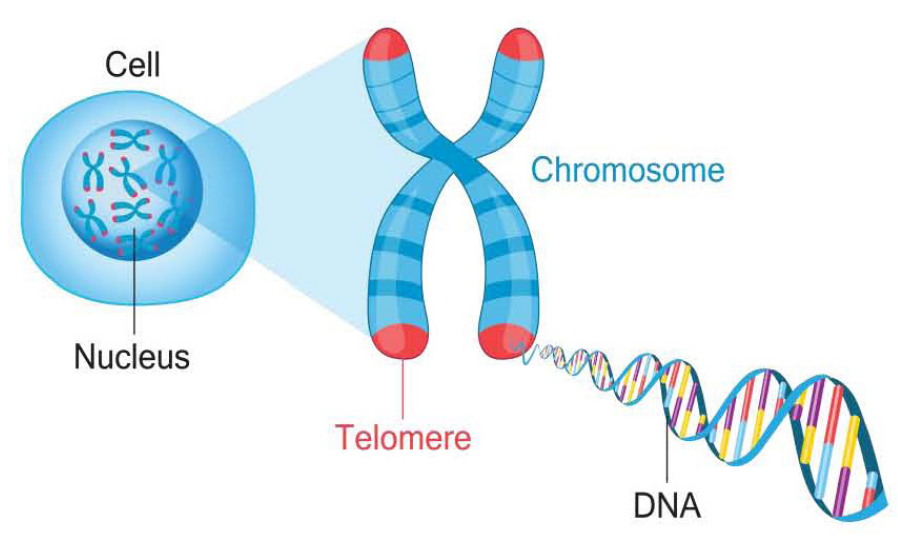

Fig. 2. Telomeres are protective caps of chromosomes (Tapis F.) (Adapted with permission by Shutterstock) 
to telomeric DNA using the RNA complementary sequence as a template, allowing the maintenance of telomere length. Telomere length is established by the outcome of two opposing forces: on one side telomere erosion generated during cell division by the end-replication problem, exonucleases, and oxidative activities; on the other side telomere elongation by telomerase and recombination-based processes known as alternative lengthening of telomeres or ALT. Greider C.W., Blackburn E.H., and Szostack J. were the first to identify the role of telomerase in chromosomal elongation in eukaryotic cells (Greider \& Blackburn, 1987) and the protective role of telomeric DNA from nucleotide degradation (Greider \& Blackburn, 1985). These great discoveries were awarded The Nobel Prize in Physiology or Medicine 2009 and shed new light on disease mechanisms and aging.

\section{Telomeres: biological clock}

Recent studies indicate that telomere length, which can be affected by various lifestyle factors, can affect the pace of aging and onset of age-associated diseases. Stem cell dysfunction provoked by telomere shortening may be one of the mechanisms responsible for organismal aging in both humans and mice. Cell replication rate, cumulative exposure to damaging agents, low activity of the telomerase enzyme are the cause of erosion of telomeres (Aviv, 2008). Agents that cause DNA damage (such as oxidative, inflammatory, endocrine and other forms of biological stress), ROS, mitochondrial damage, DNA damage, lack of micronutrients, misfolded proteins accumulation, faulty microbiome signaling, insulin resistance, IGF-1 up-regulation, mTOR and sirtuins dis-regulation, cause damage at a cellular and tissue level (DiLoreto \& Murphy, 2015). Accordingly, Funk et al. have found that telomerase expression restores dermal integrity to in vitro-aged fibroblasts in a reconstituted skin model (Funk et al., 2000) and recently it was demonstrated that telomere re-lengthening through telomerase activation could reverse aging phenotype in mice (Jaskelioff et al., 2011). It was the first time in history to invert aging process in mammals. Previous studies suggested that female human fertility decreases with increased maternal age and that various adverse factors, including alterations in telomerase activity, can contribute to age-associated infertility in women. The fact that telomerase activity is regulated in a time- and location-dependent manner in both embryo and placental tissues, highlights it potential importance to the successful completion of pregnancy. Since maternal age is a crucial determining factor for the success of in vitro and in vivo fertilization, numerous studies have focused on telomerase activity and its correlation with mammalian fertilization, as well as the following cleavage and pre-implantation developmental processes. Associations between telomerase activity and pregnancy complications have been previously observed. Fragkiadaki et al. summarize and critically discuss evidence correlating telomerase activity with pregnancy complications (Fragkiadaki et al., 2016). Diverse lifestyle, environmental and nutritional factors influence positively or negatively telomere length. Some of the factors that negatively influence telomere length are smoking, alcohol, stress, vitamin $\mathrm{D}$ and $\mathrm{C}$ deficiency, obesity, oxidation and drugs (Shammas, 2011; Rode et al., 2015). On the other hand, nutrition, antioxidants, omega 3 , exercise and telomerase activators are some of the factors that positively influence telomere length (Ornish et al., 2013).

Telomere shortening is a biological clock that indicates the pace of aging (Fig. 3). Telomere length at birth can vary from 5000-15000 pair bases, so the rate of telomere shortening is a more robust biomarker than the absolute telomere length. At birth, the average telomere length 


\section{TELOMERE}

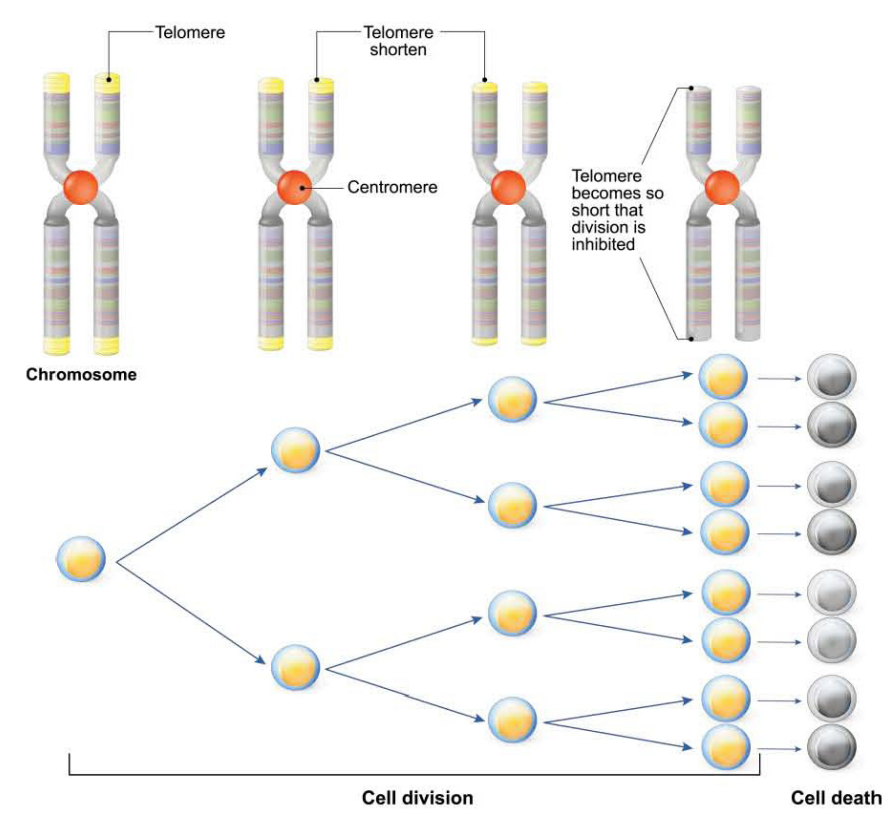

Fig. 3. Telomeres shortening and cell division (Designua) (Adapted with permission by Shutterstock)

is $10.000 \mathrm{bps}$. At 20 years of age, the average telomere length is around $8.000 \mathrm{bps}$. Gradual loss of 35-150 base pairs per year leads to telomere length of 4500 bps where the chromosomes are unstable and the probabilities of serious health problems and death increase exponentially. A person that loses 35 bps instead of 150 bps per year, ages at a five times slower pace (Lansdorp et al., 1996; Okuda et al., 2002).

\section{Rate of telomere shortening predicts longevity}

The two main methods to assess telomere length are Polymerase chain reaction (PCR) and Quantitative Fluorescence in Situ Hybridization (Q-FISH). Various methods of TL measurement have been developed as reviewed by (Montpetit et al., 2015). Terminal Restriction Fragment (TRF) analysis which gives a crude analysis of MTL, and qPCR which estimates relative levels of MTL, have been widely used in large population studies. Even though these are lowcost methods and require only minimum amount of biological sample, they present various limitations, including low sensitivity and lack of reproducibility. Importantly their inability to estimate the individual TL and detect critically short telomeres $(<3 \mathrm{~kb})$ limits their application in diagnostics. Q-FISH provides the ability to quantify the telomere length in 92 individual telomeres, gives data on short telomeres percentage and can also be used as a clinical diagnostic tool (Fernández-Alvira et al., 2016; Vera \& Blasco, 2012). Moreover, "telomere free" ends, chromosomes lacking telomere sequences large enough to be detected, require a highly sensitive methods to be identified. Q-FISH of telomeric parts in metaphase chromosomes employs highlevel methodology and equipment used by skilled cytogeneticists to assess the 184 telomeric ends in individual samples. This method provides results on median length of single telomeres, the 
percentage of short telomeres and percentage of critically short telomeres $(<3 \mathrm{~kb})$, and gives an overview of the rate of telomere shortening and longevity (Vera et al., 2012; Ledford, 2007). It is known that the rate of increase of the percentage of short telomeres predicts longevity in mammals (Vera et al., 2012).

Toxplus, a spin-off company from University of Crete, and Metabolomic Medicine of Athens have developed a semi-automated worksheet with more than 100 participants, for providing telomere length statistics. In this database a big but not enormous dataset is made for a person, each person have at least 1840 measures for an analysis (10 metaphases x 23 chromosomes x 2 chains x 4 telomeres tails), chronological age and medical history (e.g. drugs, alcohol consumption, exposure on pesticides) (Tsoukalas et al., 2018). Basic statistics and figures for each of the participant such as: percentage of critically short telomeres ( $<3000$ kbases), chromosome length distribution and graphs of biological age vs chronological person's age. The database consists of leucocyte telomere length measurements (LTL) of different age groups within a healthy adult population, through Q-FISH, creating a reference range based on age and percentile distribution of LTL. Repeated measurements at a distance of 6 months or a year can reveal the rate of change of the short telomeres, and response of patients to treatments, lifestyle, diet, supplementation and exercise modifications.

Telomerase activators are substances and methods that can activate the expression of the enzyme telomerase. Telomerase activation has been achieved through natural molecules, synthetic molecules and genetic manipulation and intervention. A natural product telomerase activator marketed since 2008, TA-65 is an extract of the herb astragalus. This has been found to lengthen telomeres in humans. The active molecule in TA-65 is cycloastragenol. Cycloastragenol can be isolated from various species in the genus Astragalus. It has been suggested to have telomerase activation activity. An in vitro study on human CD4 and CD8 T cells suggest that cycloastragenol increases telomerase activity and reduce the effects of aging (Valenzuela et al., 2009). Product B has also been suggested to be a potent telomerase activator. It is a herb nutraceutical, contains "telomere support" compounds and antioxidants and it has been promoted by Bill Andrews one of the discoverers of human telomerase, but there is no long-term test data available. The first study of the effect of telomerase activation in humans by Harley et al. was for TA- 65 which has been isolated from a proprietary extract of the dried root of Astragalus membranaceous (Harley et al., 2011). Studies on TA-65 in humans and animals support improvements in biomarkers of aging, including immune, cardiovascular, metabolic, bone (de Jesus et al., 2011). Toxplus company and Metabolomic Medicine of Athens measure telomerase activation in herbal extracts, searching for human telomerase activators. They test these in human normal peripheral blood mononuclear cells (PMBCs), using a commercial telomerase polymerase chain reaction-enzymelinked immune sorbent assay (Tsitsimpikou et al., 2013).

\section{References}

Ames B.N. (2006) Low micronutrient intake may accelerate the degenerative diseases of aging through allocation of scarce micronutrients by triage. Proc. Natl. Acad. Sci., 103: 17589-17594

Aviv A. (2008) The epidemiology of human telomeres: Faults and promises. Journals Gerontol. Ser. A Biol. Sci. Med. Sci., 63: 979-983 
Barzilai N., Crandall J.P., Kritchevsky S.B., Espeland M.A. (2016) Metformin as a tool to target aging. Cell Metab., 23: 1060-1065

Benayoun B.A., Pollina E.A., Brunet A. (2015) Epigenetic regulation of ageing: Linking environmental inputs to genomic stability. Nat. Rev. Mol. Cell Biol., 16: 593-610

Betteridge D.J. (2000) What is oxidative stress? Metabolism, 49: 3-8

Bonkowski M.S., Sinclair D.A. (2016) Slowing ageing by design: The rise of NAD+and sirtuinactivating compounds. Nat. Rev. Mol. Cell Biol., 17: 679-690

Cui H., Kong Y., Zhang H. (2012) Oxidative stress, mitochondrial dysfunction, and aging. $J$. Signal Transduct., 2012: 1-13

de Jesus B.B., Schneeberger K., Vera E., Tejera A., Harley C.B., Blasco M.A. (2011) The telomerase activator TA-65 elongates short telomeres and increases health span of adult/old mice without increasing cancer incidence. Aging Cell, 10: 604-621

DiLoreto R., Murphy C.T. (2015) The cell biology of aging. Mol. Biol. Cell, 26: 4524-4531

Designua, Telomere and cell division, Digital image ID: 488807065, Shutterstock, https://www. shutterstock.com/image-vector/telomere-cell-division-488807065?src=RKF8wfffior9lV-EatKjzg-1-8

Fernández-Alvira J.M., Fuster V., Dorado B., Soberón N., Flores I., Gallardo M., Pocock S., Blasco M.A., Andrés V. (2016) Short telomere load, telomere length, and subclinical atherosclerosis: the PESA study. J. Am. Coll. Cardiol., 67: 2467-2476

Fragkiadaki P., Tsoukalas D., Fragkiadoulaki I., Psycharakis C., Nikitovic D., Spandidos D.A., Tsatsakis A.M. (2016) Telomerase activity in pregnancy complications (Review). Mol. Med. Rep., 14: $16-21$

Frasca D., Blomberg B.B., Paganelli R. (2017) Aging, obesity, and inflammatory age-related diseases. Front. Immunol., 8: 1-10

Funk W.D., Wang C.K., Shelton D.N., Harley C.B., Pagon G.D., Hoeffler W.K. (2000) Telomerase expression restores dermal integrity to in vitro-aged fibroblasts in a reconstituted skin model. Exp. Cell Res., 258: 270-278

Greider C.W., Blackburn E.H. (1985) Identification of a specific telomere terminal transferase activity in tetrahymena extracts. Cell, 43: 405-413

Greider C.W., Blackburn E.H. (1987) The telomere terminal transferase of tetrahymena is a ribonucleoprotein enzyme with two kinds of primer specificity. Cell, 51: 887-898

Griffith J.D., Comeau L., Rosenfield S., Stansel R.M., Bianchi A., Moss H., De Lange T. (1999) Mammalian telomeres end in a large duplex loop. Cell, 97: 503-514

Harley C.B., Liu W., Blasco M., Vera E., Andrews W.H., Briggs L.A., Raffaele J.M. (2011) A natural product telomerase activator as part of a health maintenance program. Rejuvenation Res., 14: $45-56$

Heintz C., Mair W. (2014) You are what you host: Microbiome modulation of the aging process. Cell, 156: 408-411

Jaskelioff M., Muller F.L., Paik J.H., Thomas E., Jiang S., Adams A.C., Sahin E., Kost-Alimova M., Protopopov A., Cadiñanos J., Horner J.W., Maratos-Flier E., Depinho R.A. (2011) Telomerase reactivation reverses tissue degeneration in aged telomerase-deficient mice. Nature, 469: 102-107

Johnson S.C., Rabinovitch P.S., Kaeberlein M. (2013) MTOR is a key modulator of ageing and age-related disease. Nature, 493: 338-345 
Lansdorp P.M., Verwoerd N.P., Van De Rijke F.M., Dragowska V., Little M.T., Dirks R.W., Raap A.K., Tanke H.J. (1996) Heterogeneity in telomere length of human chromosomes. Hum. Mol. Genet., 5: 685-691

Ledford H. (2007) Minimum telomere length defined for healthy cells. Nature, 449: 515

Lee C., Wan J., Miyazaki B., Fang Y., Guevara-Aguirre J., Yen K., Longo V., Bartke A., Cohen P. (2014) IGF-I regulates the age-dependent signaling peptide humanin. Aging Cell, 13: 958-961

Lipton J.O., Sahin M. (2014) The neurology of mTOR. Neuron, 84: 275-291

Milman S., Atzmon G., Huffman D.M., Wan J., Crandall J.P., Cohen P., Barzilai N. (2014) Low insulin-like growth factor-1 level predicts survival in humans with exceptional longevity. Aging Cell, 13: 769-771

Montagnani S., Rueger M.A., Hosoda T., Nurzynska D. (2016) Adult stem cells in tissue maintenance and regeneration. Stem Cells Int., 7362879

Montpetit A.J., Alhareeri A.A., Montpetit M., Starkweather A.R., Elmore L.W., Filler K., Mohanraj L., Burton C.W., Menzies V.S., Lyon D.E., Jackson-Cook C.K. (2014) Telomere length: a review of methods for measurement. Nurs. Res., 63: 289-299

Muraki K., Nyhan K., Han L., Murnane J.P. (2012) Mechanisms of telomere loss and their consequences for chromosome instability. Front. Oncol., 2: 1-13

Nikolouzakis T.K., Vassilopoulou L., Fragkiadaki P., Mariolis Sapsakos T., Papadakis G., Spandidos D.A., Tsatsakis A.M., Tsiaoussis J. (2018) Improving diagnosis, prognosis and prediction by using biomarkers in CRC patients (review). Oncol. Rep., 39(6): 2455-2472

O’Sullivan R.J., Karlseder J. (2010) Telomeres: protecting chromosomes against genome instability. Nat. Rev. Mol. Cell Biol., 11: 171-181

Okuda K., Bardeguez A., Gardner J.P., Rodriguez P., Ganesh V., Kimura M., Skurnick J., Awad G., Aviv A. (2002) Telomere length in the newborn. Pediatr. Res., 52: 377-381

Ornish D., Lin J., Chan J.M., Epel E., Kemp C., Weidner G., Marlin R., Frenda S.J., Magbanua M.J.M., Daubenmier J., Estay I., Hills N.K., Chainani-Wu N., Carroll P.R., Blackburn E.H. (2013) Effect of comprehensive lifestyle changes on telomerase activity and telomere length in men with biopsy-proven low-risk prostate cancer: 5-year follow-up of a descriptive pilot study. Lancet Oncol., 14: 1112-1120

Parrella E., Longo V.D., Angeles L. (2015) Insulin/IGF-I and related signaling pathways regulate aging in nondividing cells: from yeast to the mammalian brain. Scientific World Journal, 10: 161-177

Payne B.A.I., Chinnery P.F. (2015) Mitochondrial dysfunction in aging: Much progress but many unresolved questions. Biochim. Biophys. Acta-Bioenerg., 1847: 1347-1353

Prince M.J., Wu F., Guo Y., Gutierrez Robledo L.M., O’Donnell M., Sullivan R., Yusuf S. (2015) The burden of disease in older people and implications for health policy and practice. Lancet, 385: $549-562$

Rode L., Nordestgaard B.G., Bojesen S.E. (2015) Peripheral blood leukocyte telomere length and mortality among 64637 individuals from the general population. J. Natl. Cancer Inst., 107: 1-8

Romano A., Serviddio G., de Matthaeis A., Bellanti F., Vendemiale G. (2010) Oxidative stress and aging. J. Nephrol., 23 (Suppl 15): S29-36

Shammas M.A. (2011) Telomeres, lifestyle, cancer, and aging. Curr. Opin. Clin. Nutr. Metab. Care, 14: 28-34 
Tapis F, Telomeres are protective caps on the end of chromosomes. Cell, chromosome and DNA vector illustration, Digital image ID: 710795275, Shutterstock, https://www.shutterstock.com/ image-vector/telomeres-protective-caps-on-end-chromosomes-710795275?src=Qn0xUOoPYE6 DZNxzx6gq7A-1-1

Tsitsimpikou C., Tzatzarakis M., Fragkiadaki P., Kovatsi L., Stivaktakis P., Kalogeraki A., Kouretas D., Tsatsakis A.M. (2013) Histopathological lesions, oxidative stress and genotoxic effects in liver and kidneys following long term exposure of rabbits to diazinon and propoxur. Toxicology, 307: 109-114

Tsoukalas D., Alegakis A.K., Fragkiadaki P., Vakonaki E., Tzatzarakis M., Sarandi E., Tsilimidos G., Tsatsakis A. (2018) Developing BIOTEL a semi-automated spreadsheet for the estimation of telomere length and biological age. BMC Genomics (in press)

Vakonaki E., Tsiminikaki K., Plaitis S., Fragkiadaki P., Tsoukalas D., Katsikantami I., Vaki G., Tzatzarakis M.N., Spandidos D.A., Tsatsakis A.M. (2018) Common mental disorders and association with telomere length. Biomed. Rep., 8(2): 111-116

Valenzuela H.F., Fuller T., Edwards J., Finger D., Molgora B. (2009) Cycloastragenol extends T cell proliferation by increasing telomerase activity (90.30). J. Immunol., 182: 90.30

Vera E., Bernardes de Jesus B., Foronda M., Flores J.M., Blasco M.A. (2012) The rate of increase of short telomeres predicts longevity in mammals. Cell Rep., 2: 732-737

Vera E., Blasco M.A. (2012) Beyond average: Potential for measurement of short telomeres. Aging (Albany. NY), 4: 379-392

Vilchez D., Saez I., Dillin A. (2014) The role of protein clearance mechanisms in organismal ageing and age-related diseases. Nat. Commun., 5: 56-59

Watroba M., Szukiewicz D. (2016) The role of sirtuins in aging and age-relateddiseases. Adv. Med. Sci., 61: 52-62

WHO (2011) Fact Files. 10 facts on ageing and health. Fact 3 